\title{
Optimalisasi Kemandirian Kelautan dalam Mewujudkan Pembangunan Budaya Maritim Nasional
}

Sugianto

Fakultas Hukum Universitas Muhammadiyah Cirebon, E-mail: sugianto_lkbh@yahoo.co.id

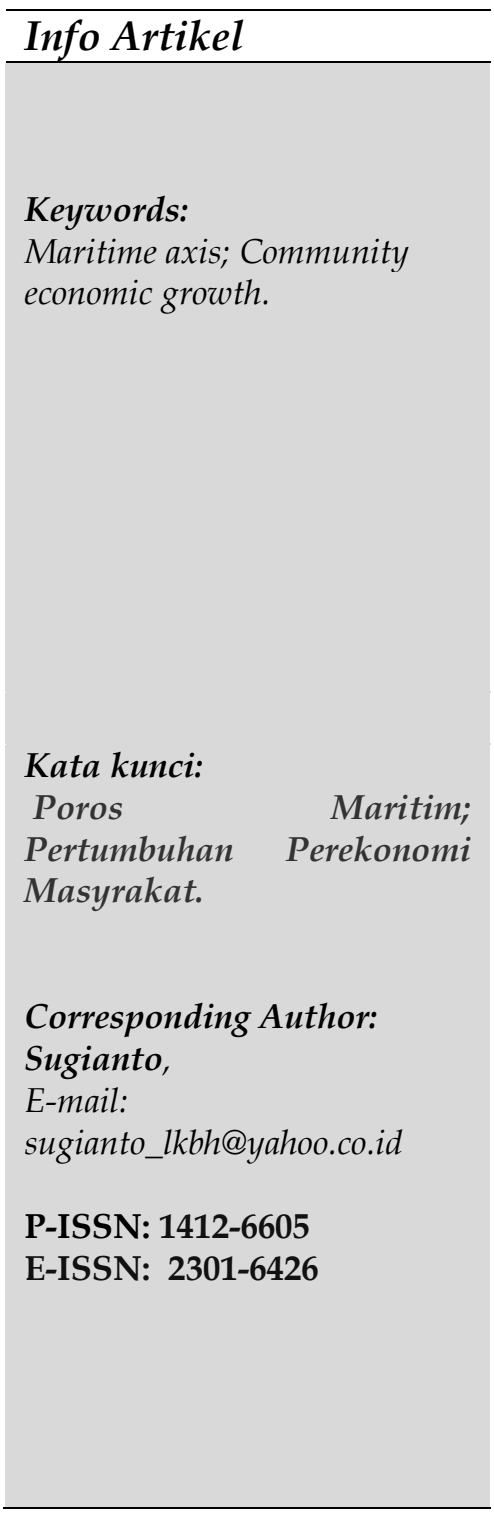

\begin{abstract}
National development is in line with the direction of the Marine Policy as outlined in the 2015-2019 RPJMN. Joko Widodo-Jusuf Kalla's Nawacita program in Point 1 is to assess itself as a maritime country and strengthen marine surveillance and build national connectivity. In realizing a maritime policy order in Indonesia, it is imperative to create independence and sovereignty in order to organize national development towards a national maritime axis. In accordance with its geographic identity, Indonesia has a vision as a World Maritime Axis. The government has a number of agendas related to this vision, including related to maritime culture development, maritime resource management, infrastructure development and maritime connectivity, diplomacy and maritime security defense. It is hoped that from the implementation of this maritime axis, Indonesia's economy and prosperity will increase.

\begin{tabular}{l} 
Abstrak \\
\hline Pembangunan nasional sesuai arah Kebijakan Kelautan yang \\
dituangkan dalam RPJMN periode 2015-2019. Program \\
Nawacita Presiden Joko Widodo-Jusuf Kalla pada Poin 1 adalah \\
untuk memperkuat jati diri sebagai negara maritim serta \\
penguatan lembaga pengawasan laut dan membangun \\
konektivitas nasional (tol laut). Dalam mewujudkan sebuah \\
tatanan kebijakan kelautan di Indonesia diharuskan wujudkan \\
kemandirian dan kedaulatan dalam rangka menata pembangunan \\
nasional menuju Poros maritim nasional. Sesuai dengan \\
karakteristik geografis yang dimilikinya, Indonesia memiliki visi \\
sebagai Poros Maritim Dunia. Pemerintah memiliki sejumlah \\
agenda terkait dengan visi tersebut diantaranya terkait dengan \\
pembangunan budaya maritim, pengelolaan sumber daya \\
maritim, pembangunan infrastruktur dan konektivitas maritim, \\
diplomasi dan pertahanan keamanan maritim. Diharapkan dari \\
diberlakukannya poros maritim tersebut perekonomian dan \\
kemakmuran Indonesia meningkat.
\end{tabular}
\end{abstract}

\section{Pendahuluan}

Indonesia sebagai negara kepulauan yang terluas di dunia yang terdiri atas lebih dari 17.504 Pulau dengan 13.466 pulau telah diberi nama dan di samping itu Indonesia merupakan negara yang memiliki wilayah laut yang sangat luas, sekitar 2/3 wilayah negara ini berupa lautan. ${ }^{1}$ Dengan cakupan wilayah laut yang

${ }^{1}$ Galuh Wahyu Kumalasari, Kebijakan Pengembangan Konsep Sea Gate International (Sgi) Guna Mewujudkan Kemandirian Maritim Indonesia, Legality, Vol.24, No.2, hlm 194 
begitu luasnya, maka Indonesia pun diakui secara internasional sebagai Negara Maritim yang ditetapkan dalam UNCLOS 1982 yang memberikan kewenangan dan memperluas wilayah laut Indonesia. ${ }^{2}$ Kelautan menjadi sektor yang sangat penting dalam percaturan perekonomian di dunia. Indonesia memiliki kewajiban untuk menunjukkan peran yang signifikan dalam kegiatan ekonomi bidang kelautan mengingat potensi Indonesia sangat besar. Pentingnya sektor kelautan dalam hubungan internasional diantaranya berkaitan dengan: ${ }^{3}$

a. Wilayah Kedaulatan Bangsa;

b. Lingkungan dan sumber daya;

c. Media kontak sosial, ekonomi dan budaya;

d. Geostrategi, geopolitik, geokultural dan geoekonomi Negara;

e. Sumber dan media penyebar bencana alam

Namun, saat ini paradigma pembangunan kita umumnya masih memusatkan perhatiannya untuk mengalokasikan sumberdaya pembangunan yang ada kepada sektor-sektor atau wilayah-wilayah yang berpotensi besar dalam menyumbang pada pertumbuhan ekonomi umumnya di wilayah daratan. Sebagaimana dikatakan oleh kementrian kelautan Indonesia pada tahun 2012, dengan berorientasi kelautan Indonesia kedepan diharapkan dapat menjadi arus utama pembangunan nasional dengan memanfaatkan ekosistem perairan laut beserta segenap sumberdaya yang terkandung di dalamnya secara berkelanjutan (on a sustainable basis) untuk kesatuan, kemajuan dan kesejahteraan bangsa. Keinginan tersebut dijabarkan dalam lima tujuan yang harus dicapai, ${ }^{4}$ yaitu:

a. Membangun jaringan sarana dan prasarana sebagai perekat semua pulau dan kepulauan Indonesia;

b. Meningkatkan dan menguatkan sumber daya manusia di bidang kelautan yang didukung oleh pengembangan ilmu pengetahuan dan teknologi;

c. Menetapkan wilayah Negara Kesatuan Republik Indonesia, aset-aset, dan hal-hal yang terkait dalam kerangka pertahanan Negara;

d. Membangun ekonomi kelautan secara terpadu dengan mengoptimalkan pemanfaatan sumber kekayaan laut secara berkelanjutan;

e. Mengurangi dampak bencana pesisir dan pencemaran laut.

Kekurangan akan hal tersebut dalam banyak pandangan pakar dikatakan bahwa atas kurangnya kemandirian Indonesia dalam pengelolaan sektor kelautan, maka jelas bahwa kemampuan untuk melakukan pengelolaan laut secara mandiri harus ditingkatkan dan direalisasikan dengan segera. Potensi laut

${ }^{2}$ Atmadja, M., 1996, Eksistensi Indonesia sebagai Negara Kepulauan, Makalah yang disampaikan pada pergerakan kebangsaan Makassar ke Serui, Yapen, Irian Jaya, tahun 1996

${ }^{3}$ Galuh Wahyu Kumalasari, Op.cit.

${ }^{4}$ Kementerian Kelautan dan Perikanan,. Kebijakan Ekonomi Kelautan dengan Model Ekonomi Biru, Jakarta, 2012. 
yang demikian besar harus dioptimalkan sehingga Indonesia dapat diperhitungkan dalam bisnis internasional pada sektor kelautan. Langkah fundamental dan visioner dengan potensi perolehan hasil yang signifikan harus menjadi prioritas. ${ }^{5}$

Sebagaimana diketahui bersama bahwa Sumber kekayaan alam yang berlimpah menjadikan wilayah laut memiliki makna yang sangat penting untuk pembangunan nasional. Posisi strategis Indonesia tidak hanya dilihat dari posisi di persilangan antara dua benua, yaitu Asia dan Australia, serta dua samudera, yaitu Samudera Pasifik dan Samudera Hindia, tetapi juga di antara Laut China Selatan dan Laut Asia Timur dengan Samudera Hindia menempatkan Indonesia pada posisi penting dalam menciptakan stabilitas politik, ekonomi serta keamanan regional dan internasional. 6 Kebijakan Pemerintah terhadap kedaulatan dan kemandirian pengelolaan kelautan sebagai wujud implementasi mewujudkan pembangunan yang lebih memperhatikan wilayah daratan perlu diubah mengingat laut merupakan sumber penghidupan di masa depan. Paradigma pembangunan di sektor kelautan yang menyimpan kekayaan alam yang luar biasa menjadi pekerjaan rumah bagi pemerintah untuk mengembalikan kejayaan bangsa ini sebagai negara maritim. Kepastian pentingnya Regulasi sebagai perundang-undangan di bidang kelautan perlu disusun dan ditetapkan sebagai jaminan yang akan memberi kepastian hukum dan akan menjadi ramburambu dalam pengelolaan pembangunan kelautan.

Bahwa Pemerrintah dibawah kendali Presiden Joko widodo - Jusuf kalla dengan Program Nawa Cita pada Poin 1 “ Menghadirkan kembali negara untuk melindungi segenap bangsa dan memberikan rasa aman pada seluruh warga negara, melalui politik luar negeri bebas aktif, keamanan nasional yang terpercaya dan pembangunan pertahanan negara Tri Matra terpadu yang dilandasi kepentingan nasional dan memperkuat jati diri sebagai negara maritim. Tentunya Gagasan Negara Maritim Indonesia sebagai aktualisasi wawasan nusantara untuk memberi gerak pada pola pikir, pola sikap dan pola tindak bangsa Indonesia secara bulat dalam aktualisasi wawasan nusantara. Pengembangan konsepsi negara maritim Indonesia sejalan dengan upaya peningkatan kemampuan bangsa menjadi bangsa yang modern dan mandiri dalam teknologi kelautan dan kedirgantaraan bagi kesejahteraan bangsa dan negara. Indonesia belum mampu menjadi negara maritim karena belum mampu mengelola kekayaan laut dan menjamin keamanan laut. Kekayaan laut yang melimpah belum mampu dimanfaatkan secara optimal bagi kemajuan perekonomian bangsa. Dalam Undang-undang (UU) Nomor 32 tahun 2014 tentang Kelautan ditegaskan dalam Pasal 3 bahwa Penyelenggraan kelautan yaitu untuk:

${ }^{5}$ Ade Prasetia, Ekonomi Kelautan Indonesia, (Yogyakarta: Diandra Kreatif, 2016), hlm 41-46

${ }^{6}$ Diah Apriani Atika Sari, Integrasi Tata Kelola Kebijakan Pembangunan Kelautan Berkelanjutan, Jurnal RechtsVinding, Vol. 8 No. 2, Agustus 2019 hlm. 148 
a. Menegaskan Indonesia sebagai negara kepulauan berciri nusantara dan maritim;

b. Mendayagunakan Sumber Daya Kelautan dan/atau kegiatan di wilayah Laut sesuai dengan ketentuan peraturan perundang-undangan dan hukum laut internasional demi tercapainya kemakmuran bangsa dan negara.

Pasal 13 “1) Pembangunan Kelautan dilaksanakan sebagai bagian dari pembangunan nasional untuk mewujudkan Indonesia menjadi negara kepulauan yang mandiri, maju, kuat, dan berbasiskan kepentingan nasional.7 Maka berdasarkan argumentasi yang penulis paparkan sebelumnya, dalam makalah ini penulis akan menjabarkan dan memaparkan secara mendalam mengenai pentingnya upaya mewujudkan Indonesia sebagai negara maritim, pentingnya membangun kedaulautan terhadap sektor kelautan, dan bagaimana langkah mewujudkan pemerintah indonesia sebagai poros maritim dunia.

\section{Metode Penelitian}

Jenis penelitian yang digunakan dalam menyusun penelitian ini adalah penelitian hukum normatif. Dengan menggunakan data sekunder. Penelitian hukum normatif mengutamakan penelitian kepustakaan, yaitu kegiatan mengumpulkan data dari berbagai literatur baik dari perpustakaan maupun tempat lain. ${ }^{8}$ Penelitian hukum normatif ini menitikberatkan pada asas-asas hukum, sistematika hukum, sinkronisasi hukum, sejarah hukum dalam pembentukan Mahkamah Konstitusi dan lembaga negara di Indonesia Penelitian ini menggunakan data sekunder. Alat pengumpulan data sekunder berupa buku-buku yang berkaitan dengan teori dan konsep objek penelitian, artikel terkait, literatur pada karya ilmiah dan lain sebagainya melalui studi literatur. ${ }^{9}$

\section{Hasil dan Pembahasan}

\section{Pentingnya Mewujudkan Indonesia Menjadi Negara Maritim}

Indonesia sebagai Negara Kesatuan yang berjumlah penduduk Kurang lebih 250 juta jiwa belum mampu menjadi negara maritim karena belum mampu mengelola kekayaan laut dan menjamin keamanan laut. Kekayaan laut yang melimpah belum dapat dimanfaatkan secara optimal bagi kemajuan perekonomian bangsa. Demikian halnya terkait keamanan laut, terutama yang berbatasan dengan negara tetangga. Ketidakjelasan batas wilayah laut serta terjadinya beberapa kasus terkait batas negara, membuat Indonesia

\footnotetext{
7Undang-undang no 32 tahun 2014 tentang kelautan, www.hukumonline.com

8 Jarot Digdo Ismoyo, The Model of Management of the Masela Block Based on People's Welfare in Maluku, Jurnal Bestuur Vol. 8, Issue 2, December, 2020. hlm 87

${ }^{9}$ Ibid.
} 
harus bekerja keras dalam membangun kelautan secara utuh menuju negara maritim yang tangguh.

Paradigma pembangunan umumnya masih memusatkan perhatiannya untuk mengalokasikan sumberdaya pembangunan yang ada kepada sektorsektor atau wilayah-wilayah yang berpotensi besar dalam menyumbang pada pertumbuhan ekonomi, yang pada umumnya berlokasi di kawasan darat. Dimana paradigma yang terus berlangsung sampai saat ini oleh para pengambil kebijakan di tingkat pusat dan daerah lebih berorientasi ke darat daripada sektor laut. Sudah saatnya bangsa kita merubah cara pandang pembangunan dari pembangunan yang semata berbasis daratan (Land based development) menjadi lebih berorientasi kepada pembangunan berbasis kelautan (Ocean based development), mengingat negara kita adalah negara kepulauan yang sudah diakui dunia dan terakomodasi dalam UUD 1945 pasal 25A

Perjuangan menuju negara maritim memang tidak mudah, namun jika seluruh bangsa ini memiliki kesamaan visi dan kebulatan tekad maka hal tersebut bukanlah hal yang mustahil. Bahwa adanya Deklarasi Djuanda 1957 dan UNCLOS 1982 memberikan peluang yang besar bagi bangsa Indonesia untuk diimplementasikan secara serius melalui kebijakan-kebijakan pembangunan nasional yang memprioritaskan orientasi yang berbasis Indonesia sebagai Negara Poros maritim. Melahirkan kebijakan pembangunan melalui perundang-undangan, pembangunan kekuatan armada pertahanan, armada perdagangan, industri dan jasa maritim yang ditunjang dengan penguasaan Iptek, merupakan upaya serius yang harus segera dilakukan menuju Indonesia sebagai Negara Maritim. ${ }^{10}$

\section{Pentingnya Membangun Kedaulautan terhadap Sektor Kelautan}

Gagasan Negara Maritim Indonesia sebagai aktualisasi wawasan nusantara untuk memberi gerak pada pola pikir, pola sikap dan pola tindak bangsa Indonesia secara bulat dalam aktualisasi wawasan nusantara. Pengembangan konsepsi negara maritim Indonesia sejalan dengan upaya peningkatan kemampuan bangsa menjadi bangsa yang modern dan mandiri dalam teknologi kelautan dan kedirgantaraan bagi kesejahteraan bangsa dan negara. Pembangunan ekonomi dalam bidang kelautan belum menjadi mainstream ekonomi Indonesia, walaupun demikian bidang kelautan yang terdiri dari enam sektor ekonomi, yakni (i) perhubungan laut, (ii) industri maritim, (iii) perikanan, (iv) wisata bahari, (v) energi dan sumberdaya mineral, (vi) Insprastrutur bangunan kelautan.

${ }^{10}$ Arsyad, R., 2012, Kelautan atau Maritim?, shnews.co, Rabu, 13 Juni 2012 
Indonesia belum mampu mewujudkan negara Poros maritim karena belum mampu mengelola kekayaan laut dan menjamin keamanan laut. Kekayaan laut yang melimpah belum mampu dimanfaatkan secara optimal bagi kemajuan perekonomian bangsa. Demikian halnya terkait keamanan laut, terutama yang berbatasan dengan negara tetangga. Perbatasan wilayah laut serta terjadinya beberapa kasus terkait batas negara, membuat Indonesia harus bekerja keras dalam membangun kedaulatan dan kemandirian dalam pengelolaan kelautan secara utuh menuju negara maritim yang tangguh.

Pemerintah Indonesia dalam mewujudkan kedaulatan sebagai negara maritim yang kuat, mandiri dan berpihak pada kesejahteraan rakyat, yaitu penyusunan Undang-Undang Kelautan dan Kebijakan Kelautan Indonesia sebagai syarat untuk mewujudkan negara maritim yang sejati. Dalam Undang-undang no 23 tahun 2014 tentang Pemerintahan Daerah " bahwa dengan semangat Otonomi Daerah bahwa Pemerintah daerah kab/kota sudah tidak ada lagi kewenangan dalam mengelola batas laut namun diberikan kewenagan terhadap Daerah Propinsi dalam mengelola laut dengan batas 0-12 mil laut. ${ }^{11}$ Dengan landasan regulasi tersebut tentunya Pemerintah Indonesia dalam rangka mewujudkan kedaulatan terhadap kebijakan kelautan dapat terwujud Poros maritim sesuai yang diamanatkan dalam Nawa Cita poin satu (1).

Bahwa Negara Indonesia merupakan negara yang memiliki potensi sumberdaya alam dan budaya. Pemanfaatan sumberdaya alam dan budaya tersebut memerlukan kebijakan dan regulasi yang menyeleluruh untuk kepentingan dalam rangka membangun sinergitas antara Pemerintah Pusat, Pemerintah Daerah Propinsi, Masarakat dan Pengusaha . Sinergitas antara Pemerintah Pusat dan Daerah pun menjadi hal mendasar dalam terwujudnya cita-cita bangsa. Potensi kekayaan Indonesia yang berupa potensi pariwisata, mineral tambang dan energi, dan perikanan (tangkap dan budidaya), seharusnya dapat mewujudkan kesejahteraan masyarakat secara luas dan merata. Pembangunan Indonesia berbasis ekonomi kelautan yang berkelanjutan akan mempercepat pemerataan untuk mencapai kesejahteraan bangsa. Pembangunan ekonomi kelautan juga dapat mendukung masyarakat Indonesia dalam menghadapi Masyarakat Ekonomi Asean (MEA). ${ }^{12}$

11Undang-undang no 23 tahun 2014 Tentang Pemerintahan Daerah “ Kewenangan Daerah Propinsi terhadap pengelolaan batas laut,

12 Hanum, W.N, Setting of Earth Oil Management in Old Wells Based on the Principle Social Justice, Jurnal Bestuur Vol. 8, Issue 2, December, 2020. hlm 95 
Kebijakan Kelautan Indonesia (KKI) merupakan salah satu solusi dalam mendorong pertumbuhan ekonomi, kesejahteraan rakyat, dan menciptakan keamanan rakyat, serta mempertahankan kedaulatan Republik Indonesia. Kebijakan yang memiliki keterpaduan dan sinergitas pihak-pihak yang terkait seperti kementerian, lembaga, dinas, pemerintah pusat dan daerah, maupun pihak-pihak swasta, sehingga dapat mewujudkan Indonesia sebagai negara kepulauan (Negara Maritim) yang mandiri, maju, kuat, dan berbasiskan kepentingan nasional sesuai salah satu misi dari Undang-Undang Nomor 17 Tahun 2007. Dalam Program NawaCita Presiden Joko widodo - Jusuf Kalla merupakan agenda prioritas pembangunan nasional pemerintah yang dituangkan dalam arah Kebijakan Nasional sesuai RPJMN periode 2015-2019 yaitu pada poin 1-4 dengan mengedepankan sebuah tantangan Pemerintah dalam rangka mewujudkan kebijakan kelautan terhadap terbangunnya poros maritim. “

a. Memperkuat jati diri sebagai negara maritim melalui: penyelesaian tata batas dan batas landas kontinen di luar 200 mil laut,; serta penguatan lembaga pengawasan laut.

b. Pemberantasan tindakan perikanan liar melalui peningkatan koordinasi dalam penanganan pelanggaran tindak pidana.

c. Membangun konektivitas nasional (tol laut) dengan meningkatkan pembangunan sistem transportasi multimoda; serta melakukan upaya keseimbangan antara transportasi yang berorientasi nasional dengan transportasi yang berorientasi lokal dan kewilayahan.

d. Pengembangan ekonomi maritim dan kelautan dengan percepatan pengembangan ekonomi kelautan; meningkatkan dan mempertahankan kualitas, daya dukung dan kelestarian fungsi lingkungan laut; meningkatkan wawasan, budaya bahari, pengutan SDM dan Iptek Kelautan; serta meningkatkan harkat dan taraf hidup nelayan serta masyarakat pesisi

Peran Pemerintah terhadap pembangunan sektor kelautan, merupakan program kegiatan lintas sektor (Kementerian/Lembaga) yang melibatkan banyak stakeholder, untuk itu perlu ada satu benang merah atau grand desain yang dapat dijadikan acuan bagi seluruh pihak, sehingga kegiatan pembangunan kelautan lebih sinergis, terkoordinir, dan terukur. Grand Desain pembangunan kelautan tersebut dituangkan dalam bentuk Kebijakan Kelautan Nasional (National Ocean Policy) yang ditetapkan dalam suatu 
Peraturan Perundang-Undangan guna mengikat seluruh pihak dan menjadi landasan untuk ditaati.

Selain itu, pembangunan kelautan harus diarahkan pada prinsip pembangunan berkelanjutan (sustainable development). Pembangunan yang memenuhi kepentingan hidup generasi saat ini tanpa mengabaikan kepentingan generasi mendatang untuk hidup dan memenuhi kebutuhannya atas lingkungan hidup dan sumber daya kelautan. Pembangunan kelautan Indonesia dilaksanakan sebagai bagian dari pembangunan nasional untuk mewujudkan Indonesia menjadi negara kepulauan yang mandiri, maju, kuat dan berbasiskan kepentingan nasional. ${ }^{13}$ Salah satu langkah yang harus dilakukan adalah menyusun konstruksi kebijakan pembangunan kelautan. Untuk mewujudkan pembangunan kelautan yang komprensif dapat dilakukan melalui pendekatan; sosial budaya, ekonomi, serta politik, pertahanan dan keamanan. Pendekatan pertama yaitu sosial budaya. Pentingnya pendekatan sosial budaya didasarkan pada proses pengkajian pengenalan bangsa Indonesia sebagai negara maritim dan bangsa pelaut yang berpandangan bahwa laut merupakan potensi yang dapat dimanfaatkan untuk kesejahteraan masyarakat. ${ }^{14}$

Aspek sosial budaya sebagai bangsa maritim akan menempatkan Indonesia untuk tidak melepaskan akar sejarahnya sehingga sistem pembelajaran sebagai bangsa maritim harus ditanamkan sejak dini pada generasi muda mulai tingkat terendah sampai tertinggi. Sistem pembelajaran budaya maritim terutama generasi muda bertujuan untuk mengenalkan dan menanamkan potensi serta kekuatan bangsa. Pembelajaran dimulai dengan mengenalkan jati diri bangsa dan bagaimana kehidupan sebagai bangsa maritim dengan memasukkan ke dalam kurikulum baik di tingkat dasar sampai perguruan tinggi. Materi pembelajaran dirancang dengan memberikan muatan budaya maritim serta potensi kelautan Indonesia. Selain itu untuk penguatan budaya maritim diperlukan juga dorongan dari Pemerintah untuk membangun perguruan tinggi berbasis maritim. Dengan demikian restorasi budaya maritim akan berkesinambungan dan diharapkan generasi muda memiliki kesadaran untuk menempatkan kepentingan laut dalam pembangunan nasional. Sehingga sebagai negara maritim, rakyat Indonesia menyakini bahwa laut merupakan sumber kekayaan, sarana pemersatu bangsa, media diplomasi, media perhubungan, serta media pertahanan dan keamanan. ${ }^{15}$

13Pasal 13 Undang-Undang Nomor 32 Tahun 2014 Tentang Kelautan

${ }^{14}$ Laporan Tim Harmonisasi Kementerian PPN/Bappenas, Departemen Kelautan dan Perikanan dan Departemen Hukum dan Hak Asasi Manusia bekerjasama dengan Mitra Pesisir, "Menuju Harmonisasi Sistem Hukum Sebagai Pilar Pengelolaan Wilayah Pesisir Indoensia", 2005.

${ }^{15}$ Diah Apriani Atika Sari, Integrasi Tata Kelola Kebijakan Pembangunan Kelautan Berkelanjutan, Jurnal RechtsVinding, Vol. 8 No. 2, Agustus 2019.. hlm 156 
Kedua, pendekatan ekonomi. Kebijakan ekonomi kelautan bertujuan untuk menjadikan laut sebagai prime mover pembangunan ekonomi untuk meningkatkan kesejahteraan masyarakat. Kelautan menjadi faktor penting untuk mendukung pembangunan dari sektor ekonomi sehingga Indonesia perlu mengubah paradigma dari land based development menjadi oceanbased development yaitu wawasan dan pola pikir yang memandang potensi pembangunan tidak hanya bersumber dari darat (land based) tetapi juga dari laut (ocean based). Pembangunan kelautan melalui paradigma ocean based development memerlukan landasan konseptual dan legalitas yang jelas untuk pembangunan nasional. Landasan konseptual dalam pembangunan kelautan dimulai dengan menentukan arah pengelolaan sumber daya secara optimal sesuai dengan potensi yang ada. Pada prinsipnya, Pemerintah harus mendorong semua elemen di dalam masyarakat untuk menciptakan produk unggulan yang komparatif dan kompetitif baik di pasar nasional dan internasional. Langkah berikutnya diperlukan internaslisasi dalam kehidupan masyarakat Indonesia melalui ideologi kerakyatan yang digali dan dikembangkan dari Ideologi Pancasila. ${ }^{16}$

Ketiga, pendekatan politik, pertahanan dan keamanan. Bagi bangsa Indonesia, laut merupakan bagian integral dari wilayah negara yang tidak dapat dibagi-bagi, tetapi bisa dibedakan menurut rezim yang mengatur sebagaimana diatur dalam UNCLOS 1982. Posisi silang Indonesia yang terletak diantara benua Asia dan Australia serta diantara Samudera Pasifik dan Samudera Hindia dipengaruhi kondisi konstelasi geografis Indonesia sebagai negara kepulauan. Posisi strategis ini juga berpengaruh pada kondisi politik, ekonomi, dan keamanan Indonesia. ${ }^{17}$

Selanjutnya terkait dengan keamanan kelautan kawasan Asia Tenggara, ada beberapa permasalahan yang harus dihadapi dan memerlukan kerjasama untuk mengatasi permasalahan tersebut, antara lain: konflik perbatasan karena tumpang tindih klaim atas wilayah laut, pembajakan (sea piracy and armed robbery), terorisme, kejahatankejahatan transnasional (transnational organized crimes), keamanan pelayaran, dan perlindungan lingkungan laut. Dalam perspektif kepentingan nasional, tantangan yang dihadapi Indonesia adalah menjaga keamanan wilayah laut Indonesia dari ancaman kekuatan asing, antara lain: konflik perbatasan, potensi ancaman terorisme kelautan di choke point, berbagai kegiatan illegal fishing, illegal logging, illicit small arms trafficking, illicit, people trafficking, illicit drugs trafficking, smuggling, permasalahan lingkungan hidup. Dengan kata lain permasalahan keamanan domestik juga merupakan permasalahan yang terjadi di kawasan Asia

${ }^{16}$ Singgih Tri Sulistiyono, "Paradigma Maritim Dalam Membangun Indonesia: Belajar dari Sejarah", Lembaran Sejarah, Volume 12 Nomor 2 Oktober 2016, hlm. 101-102.

17 Diah Apriani Atika Sari., Op.cit. hlm 157 
Tenggara. Untuk mewujudkan keamanan laut diperlukan upaya penegakan kedaulatan dan penegakan hukum. ${ }^{18}$

Keamanan laut merupakan rangkaian mulai dari persepsi atau pemahaman segenap komponen bangsa, struktur organisasi, serta prosedur dan mekanisme penyelenggaraan keamanan yang memiliki kewenangan dalam penegakan kedaulatan dan penegakan hukum di laut. Untuk memperkuat penegakan hukum di laut beberapa badan telah dibentuk dalam menyelesaikan tumpang tindih kewenangan.

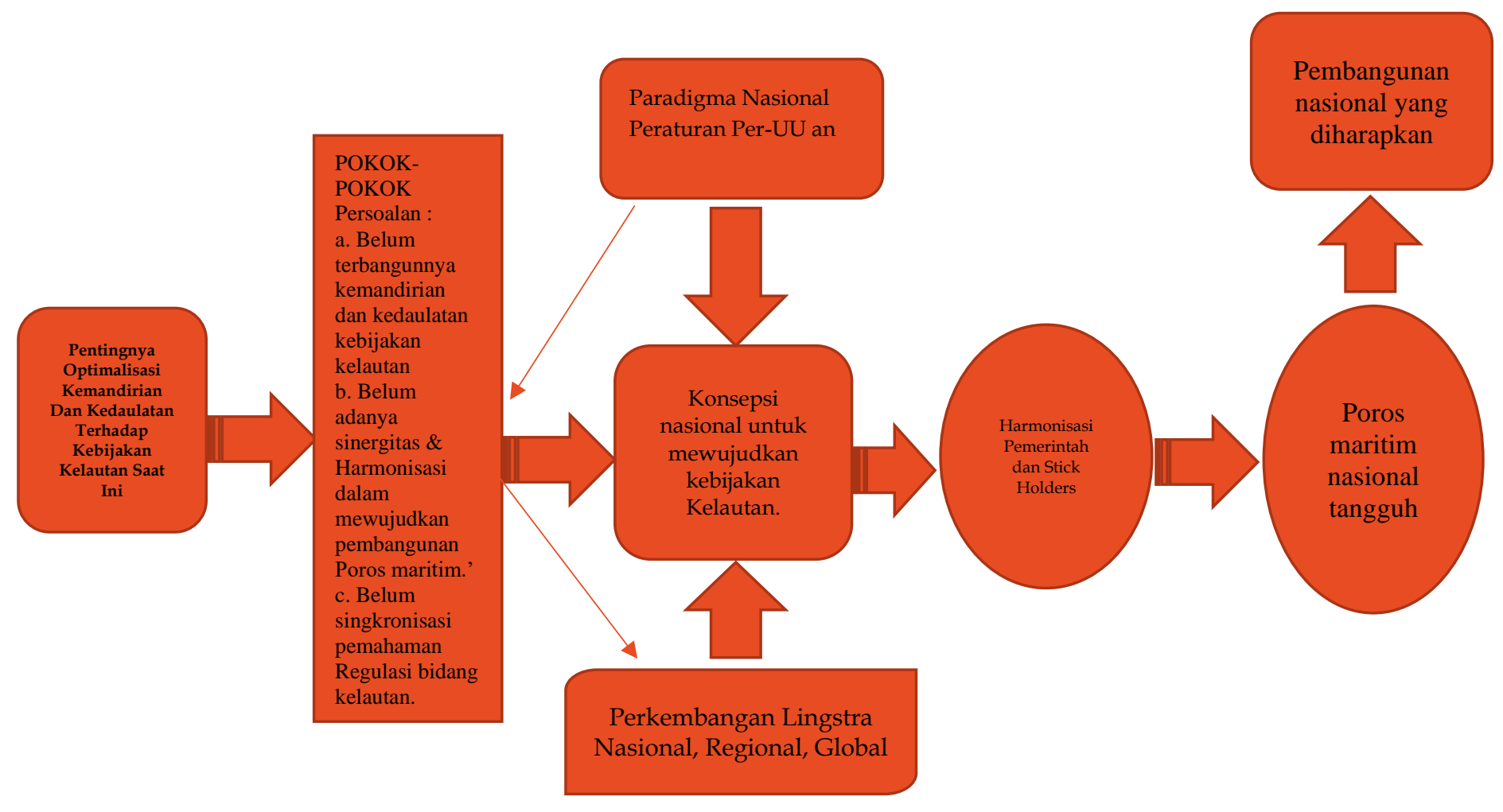

\section{Bagan 1. Konsep Optimalisasi Kemandirian dan Kedaulatan Kebijakan Kelautan Dalam Mewujudkan Pembangunan Budaya Maritim Nasional}

\section{Kesimpulan}

Dalam penulisan makalah diatas dapat ditarik kesimpulan sebagai berikut : a. Pemerintah dapat mewujudkan kebijakan kelautan yang berlandaskan pada Program Kebijakan Nasional Indonesia sesuai dengan tuntutan RPJMN Periode 2015-2019, b. Bahwa Kebijakan Kelautan Indonesia (KKI) dapat menjadi sebuah salah satu solusi dalam mendorong pertumbuhan ekonomi, kesejahteraan rakyat, dan menciptakan keamanan rakyat, serta mempertahankan kedaulatan

18 Marsetio, "Mengembalikan Kejayaan Kelautan Indonesia", (Bogor: Penerbit Universitas Pertahanan, 2018), hlm. 144-146. 
Republik Indonesia, dengan tujuan tersebut dapat mewujudkan tatanan Pemerintah dapat menata Graind Desain Pembangunan Nasional, c. Bahwa Pemerintah Pusat dan Pemerintah Daerah Propinsi dapat mewujudkan pembangunan kebijakan Kelautan melalui terbangunnya sinergitas \& Harmonisasi bersama StackHolder " Pengusaha, Masarakat, NGO.

\section{REFRENCES}

Kumalasari, G.W, Kebijakan Pengembangan Konsep Sea Gate International (Sgi) Guna Mewujudkan Kemandirian Maritim Indonesia, Legality, Vol.24, No.2,

M, Atmadja, (1996), Eksistensi Indonesia sebagai Negara Kepulauan, Makalah yang disampaikan pada pergerakan kebangsaan Makassar ke Serui, Yapen, Irian Jaya, tahun 1996

Kementerian Kelautan dan Perikanan,. Kebijakan Ekonomi Kelautan dengan Model Ekonomi Biru, Jakarta, 2012.

Prasetia, Ade. (2016). Ekonomi Kelautan Indonesia, Yogyakarta: Diandra Kreatif.

Sari, D.A.A, Integrasi Tata Kelola Kebijakan Pembangunan Kelautan Berkelanjutan, Jurnal RechtsVinding, Vol. 8 No. 2, Agustus 2019.

Ismoyo, J.D, The Model of Management of the Masela Block Based on People's Welfare in Maluku, Jurnal Bestuur Vol. 8, Issue 2, December, 2020. hlm 87

Arsyad, R., 2012, Kelautan atau Maritim?, shnews.co, Rabu, 13 Juni 2012.

Jaelani, A.K, Implementasi Daluarsa Gugatan Dalam Putusan Peradilan Tata Usaha Negara di Indonesia, Pena Justisia: Media Komunikasi dan Kajian Hukum. Volume 18, No. 2, 2019.

Hanum, W.N, Setting of Earth Oil Management in Old Wells Based on the Principle Social Justice, Jurnal Bestuur Vol. 8, Issue 2, December, 2020.

Intaniasari, Kirana, Gross Split Contract Framework Regulation on the Caring for People, Jurnal Bestuur Vol. 8, Issue 2, December, 2020.

Saputra, Rian, Development of Creative Industries as Regional Leaders in National Tourism Efforts Based on Geographical Indications, Jurnal Bestuur Vol. 8, Issue 2, December, 2020.

Akhmaddhian, Suwari. Discourse on Creating a Special Environmental Court in Indonesia to Resolve Environmental Disputes, Jurnal Bestuur Vol. 8, Issue 2, December, 2020.

Pane, E \& Yanis, A.M, Reconstruction of Mining Policies on Justice in Lampung Province, Jurnal Bestuur Vol. 8, Issue 2, December, 2020.

Gunawan, Said, The Principle of Control of Non Primary Gun System of the Indonesian National Army Protect Soldiers, Jurnal Bestuur Vol. 8, Issue 2, December, 2020.

Luthviati, R.D, The Role of Local Governments in the Defense of Leading Products, Jurnal Bestuur Vol. 8, Issue 2, December, 2020.

Sulistiyono, S.T., Paradigma Maritim Dalam Membangun Indonesia: Belajar dari Sejarah, Lembaran Sejarah, Volume 12 Nomor 2 Oktober 2016

Marsetio, (2018), Mengembalikan Kejayaan Kelautan Indonesia, (Bogor: Penerbit Universitas Pertahanan)

Abdul Kadir Jaelani, "Implementasi Daluarsa Gugatan Dalam Putusan Peradilan Tata Usaha Negara Di Indonesia", Jurnal Pena Justisia, Vol.18, Nomor 2 Tahun 2019. 
Nurika Latiff Hikmawati "Efektivitas Penerapan Sanksi Pidana Penjara Terhadap Anak Yang Melakukan Tindak Pidana", Jurnal Pena Justisia, Vol.18, Nomor 2 Tahun 2019.

Miftahur Rahman Hakim, Nur Kholidah, "Hak Merek Sebagai Jaminan Gadai Untuk Permodalan Umkm Industri Kreatif Kerajinan Batik", Jurnal Pena Justisia, Vol.18, Nomor 2 Tahun 2019.

Vidya Noor Rachmadini "Perlindungan Hukum Bagi Investor Dalam Pasar Modal Menurut Undang-Undang Pasar Modal Dan Undang-Undang Otoritas Jasa Keuangan", Jurnal Pena Justisia, Vol.18, Nomor 2 Tahun 2019.

Willy Naresta Hanum, "Setting of Earth Oil Management in Old Wells Based on the Principle Social Justice", Jurnal Bestuur, Volume 8, Nomor 2 Tahun 2020.

Resti Dian Luthviati, "The Role of Local Governments in the Defense of Leading Products", Jurnal Bestuur, Volume 8, Nomor 2 Tahun 2020. 